\title{
Kişilerarası İletişim Yetkinliği Envanteri’nin (KİYE) Türkçeye Uyarlanması
}

\author{
Özkan ÇIKRIKÇI \\ Tokat Gaziosmanpaşa Üniversitesi \\ ozkanc61@hotmail.com \\ ORCID ID: 0000-0002-9789-5888 \\ Enes ÇİNPOLAT \\ Ordu Üniversitesi \\ enescinpolat@gmail.com \\ ORCID ID: 0000-0002-3411-4300
}

\begin{tabular}{lrr} 
Araştırma Makalesi & DOI: $10.31592 /$ aeusbed.908975 \\
\hline Geliş Tarihi: 03.04.2021 & Revize Tarihi: 28.07.2021 & Kabul Tarihi: 30.07 .2021
\end{tabular}

\section{Atıf Bilgisi}

Çıkrıkçı, Ö. ve Çinpolat, E. (2021). Kişilerarası İletişim Yetkinliği Envanteri’nin (KİYE) Türkçeye uyarlanması. Ahi Evran Üniversitesi Sosyal Bilimler Enstitüsü Dergisi, 7(2), 757-775.

\section{ÖZ}

$\mathrm{Bu}$ çalışmada, Huang ve Lin (2018) tarafından geliştirilen Kişilerarası İletişim Yetkinliği Envanteri'ni (KIYE) Türkçeye uyarlamak amaçlanmıştır. $\mathrm{Bu}$ amaç doğrultusunda bağımsız dört farklı çalışma yürütülmüştür. KIYE'nin geçerlik ve güvenirliği belirlemek için dil geçerliği $(\mathrm{N}=45)$, yapı geçerliği $(\mathrm{N}=$ 208), güvenirlik ve madde analizi $(\mathrm{N}=211)$, ölçüt ve ayırt edici geçerliği $(\mathrm{N}=370)$ incelenmiştir. Geçerlik ve güvenirlik prosedürlerine dil geçerliği ile başlanmış ve KIYE'nin hedef dilde (Türkçe) geçerli olduğu sonucuna ulaşılmıştır. İkinci aşamada ölçme aracının yapı geçerliği değerlendirilmiştir. Huang ve Lin (2018) tarafından belirlenen dört faktörlü yapının (dinleme becerisi, sosyal rahatlık becerisi, empati becerisi, ifade becerisi) Türk örnekleminde geçerli olduğu doğrulayıcı faktör analizi sonucunda belirlenmiştir. Üçüncü aşamada, ölçme aracını güvenirliği iç tutarlık katsayıları aracılığıyla sınanmıştır. Güvenirlik analizi ile ilgili bulgular, KİYE'nin Türkçe formunun güvenilir olduğunu desteklemektedir. Araştırmanın son aşamasında ölçme aracının ölçüt ve yapı geçerliği araştırılmıştır. Ölçüt geçerliği kapsamında KIYE toplam puanları ile İletişim Becerileri Ölçeği toplam puanları arasındaki korelasyon ele alınmıştır. İki ölçme aracı arasındaki korelasyon değeri, KIYYE’nin ölçüt geçerliğini sağladığına ilişkin güçlü bulgular sunmaktadır. Son olarak KIYYE'nin ayırt edici geçerliği araştırılmıştır. Kurulan regresyon modelinden elde edilen bulgulara göre, KIYYE'nin kabul edilebilir düzeyde ayırt edici geçerliğe sahip olduğu ifade edilebilir. Sonuç olarak, KIYYE'nin Türkçeye uyarlaması sürecinde elde edilen bulgular ölçme aracının geçerli ve güvenilir olduğunu yansıtmaktadır. Kişilerarası iletişim yetkinliğinin oldukça geniş bir kullanım alanına sahip olduğu alan yazında açıkça belirtilmiştir. KIYYE Türkçe formunun özellikle eğitim ve psikoloji çalışmalarına önemli katkılarının olacağı düşünülmektedir.

Anahtar Kelimeler: Kişilerarası iletişim yetkinliği, iletişim, envanter, ölçek uyarlama.

\section{Adaptation of the Interpersonal Communication Competence Inventory (ICCI) into Turkish}

\begin{abstract}
In current paper, it was aimed to adapt the Interpersonal Communication Competence Inventory (ICCI) developed by Huang and Lin (2018) into Turkish. For this purpose, four independent studies were conducted. To determine the validity and reliability of ICCI, language equivalence $(\mathrm{N}=45)$, structural validity $(\mathrm{N}=$ $208)$, reliability and item analysis $(\mathrm{N}=211)$, convergent and discriminant validity $(\mathrm{N}=370)$ were examined. Validity and reliability procedures were started with language equivalence and it was concluded that ICCI was valid in the target language (Turkish). In the second phase, the structural validity of the measure was evaluated. As a result of the confirmatory factor analysis, it was determined that the four-factor structure (listening skill, social relaxation skill, empathy skill, expressiveness skill) determined by Huang and Lin (2018) was valid in the Turkish sample. In the third phase, the reliability of the measure was tested through internal consistency coefficients. Reliability analysis results supported that the Turkish form of ICCI was reliable. In the last phase of the research, the convergent and discriminant validity of the measure was investigated. Within the scope of convergent validity, the correlation between ICCI total scores and Communication Skills Scale total scores was considered. The correlation value between the two measures provided strong evidence that ICCI had the convergent validity. Finally, the discriminant validity of ICCI was investigated. According to the findings obtained from the established regression model, it would be stated that ICCI had an acceptable level of discriminating validity. As a result, the results obtained during the adaptation of ICCI into Turkish reflected that the measure was valid and reliable. It was clearly stated in the literature
\end{abstract}


that interpersonal communication competence has a wide range of usages. It would be thought that the Turkish version of ICCI will have significant contributions especially to education and psychology studies.

Keywords: Interpersonal communication competence, communication, inventory, scale adaptation.

\section{Giriş}

İnsan varoluşunun merkezinde iletişim yer almaktadır. İnsanların büyük bir çoğunluğu zamanlarının \%80 ile \%90 arasındaki zaman dilimini diğer insanlarla iletişim kurarak geçirirler (Klemmer ve Snyder, 1972). Bu etkileşim yoluyla kişilerarası ilişkilerin gelişimi sağlanmaktadır (Graham ve Shue, 2000). Kişilerarası iletişimin anlaşılabilmesi için iletişimin iki temel kategoride ele alınması gerekmektedir: genel bir kavram olarak iletişim (i) ve insan iletişimi (ii). Genel bir bağlamda iletişim, bilginin harekete geçirilme sürecidir (Beebe, Beebe ve Redmond, 2014). İnsan iletişimi ise dünyayı anlamlandırma süreci olarak ele alınabilir. Aynı zamanda, insan iletişimi sözlü ve sözsüz mesajlar yoluyla oluşturulan anlamın yukarıda ifade edilen anlamlandırma sürecinde diğer insanlarla paylaşılmasıdır (Carl ve Duck, 2004). Kişilerarası iletişimin, ilişkileri yönetebilme gibi önemli bir ayırt edici özelliği bulunmaktadır. Kişilerarası iletişim sadece iletişimde bulunulan insanların sayısı ile tanımlanamaz. Kişilerarası iletişimde, iletişimin niteliği oldukça önemli bir fonksiyona sahiptir (Aydın, 1997; Dağıstan ve Çalışkan, 2018; Kart ve Çalışkan, 2019). Kişilerarası iletişim, diğer bireylerin varoluşuna saygı gösterildiğinde belirginleşmektedir. İletişim sürecinde yetkin olabilmek arzu edilen bir kazanımdır (Beebe vd., 2014). Bu yetkinliğin sağlanabilmesi algılanan mesajlara etkili ve uygun tepki vermeyi gerektirir (Wilson ve Sabee, 2003). Aktarılan mesajların diğer insanlar tarafından anlaşılması ve mesajın arzu edilen etkiyi oluşturması bireyin etkili iletişim kurabildiğinin göstergesidir (Beebe vd., 2014). Yapılan bu çıkarımlar kişilerarası iletişim yetkinliği kavramını öne çıkarmaktadır.

Kişilerarası iletişim yetkinliği, iletişim durumlarındaki kişilerarası ilişkilerin düzenlenebilmesinde bireysel bir yeterliğe işaret etmektedir. Bu yeterlik, birçok spesifik bireysel özelliği içermektedir (Rubin ve Martin, 1994). Bilgili, yetenekli ve güdülenmiş olmak kişilerarası iletişim yetkinliği için en temel gereklilikler arasında gösterilmektedir (Almeida, 2004). İletişim konusunda bilgili olarak değerlendirilebilecek bireyler, iletişimin doğasını ve nasıl işlediğini bilmektedir. Bu bireylerin, iletişim sürecinin bileşenlerini, ilkelerini ve kurallarını içselleştirdikleri kabul edilmektedir. Bu bileşenler kişilerarası etkililiğin sürdürülmesi açısından bir gereklilik olarak görülmekle beraber, bu bilgi ya da kazanımlar tek başına kişilerarası iletişim yetkinliğini kazandıramamaktadır (Beebe vd., 2014). Yetenekli olmak, kişilerarası iletişim yetkinliğinde gerekli olan bir diğer özelliktir. İletişim sürecinde yetenekli olma durumu, bilginin eyleme nasıl dönüştürüleceği ile ilişkilendirilmektedir (Miller ve de Winstanley, 2002). Bu özelliğin geliştirilebilmesi için birey, kendi eylemlerinin uygunluğunu doğrulayabilen diğer bireylerden yararlı ve işe dönük geri bildirimlere gereksinim duymaktadır (Carrell ve Wilmington, 1996). Üçüncü gereklilik olarak güdülenme öne çıkmaktadır. Becerinin türü ne olursa olsun bir becerinin geliştirilebilmesi için üzerinde çalışılması gerekmektedir. Birey bilgisini ve yeteneklerini kullanmaya güdülenmelidir. Kişilerarası iletişimde yetkin olmak isteyen birey kendini geliştirmeye ve diğer insanlarla iletişim halinde olmaya yönelik bir arzuya sahip olmak zorundadır (Beebe vd., 2014).

Kişilerarası iletişim yetkinliğini açıklamak için çeşitli yaklaşımlar kullanılmaktadır. Temel, kişilerarası, sosyal, sözel, iletişimsel ve ilişkisel yaklaşımlar kişilerarası yetkinlik kavramının kuramsal yapısını oluşturmaktadır (Spitzberg ve Cupach, 1984). Kişilerarası İletişim Yetkinliği Envanteri (KIYYE), ilişkisel yaklaşımın doğasına ve bileşenlerine uygun olarak geliştirilmiştir (Huang ve Lin, 2018). İlişkisel yaklaşım, uygun ve etkili davranışlar arasındaki çift yönlü ilişkiye odaklanmaktadır. Aynı zamanda, ilişkisel yaklaşım bireysel hedeflere ulaşabilmek için gerekli olan becerileri ve duyarlılı̆̆ 1 göz önünde bulundurmaktadır (Spitzberg, 1983). Eğer bir davranış uygun olarak kabul görmüyorsa iki olasılığın vuku bulmuş olabileceği değerlendirilmektedir. İlk olasıllı̆a göre, durum ya da davranış ile ilgili sosyal kurallar önemsenmemiş olabilir. İkinci olasılı̆̆a göre ise, kurallar kasıt olmaksızın ihmal edilmiş olabilir ve bu durum da yanlış anlaşılmaların oluşmasına zemin hazırlayabilir. Ayrıca, insanlar iletişimin ne kadar etkili olduğuna da karar verebilirler. İletişimin etkililiğinin sınanması, amaç yönelimli davranışa dayandırılmaktadır (McCroskey, 1982). Eğer 
iletişim bir amacın başarıya ulaşmasını sağlıyorsa, bu durum iletişimin etkililiğinin göstergesi olarak değerlendirilmektedir. Kişilerarası iletişim sürecinde uygun ve etkili performans sergileyebilmek için çeşitli özelliklerin bireyde bulunması gerekmektedir (Bochner ve Kelly, 1974). Yukarında, kişilerarası iletişim yetkinliğinin sergilenebilmesi için gerekli üç temel bireysel özellikten (bilgili, yetenekli ve güdülenmiş olmak) söz edilmiştir. Bu üç özellik, kişilerarası iletişim yetkinliğinin sergilenmesinde olmazsa olmaz koşuldur. Ancak, arzu edilen kişilerarası iletişim yetkinliğine erişebilmek için bu üç özelliğin yanında bireylerin bazı becerilere sahip olmaları gerekmektedir. Kendini açma, empati, sosyal rahatlama, iddialı olma, etkileşim yönetimi, diğeri-odaklılık, ifade edicilik (dışavurumluk), destekleyici olma, samimiyet, çevresel kontrol (Rubin ve Martin, 1994) ve öz-düzenleme (Aydın, 2018) kişilerarası iletişim yetkinliğinin sergilenmesi önemli role sahip olan becerilerdir.

Huang ve Lin (2018), ilişkisel yaklaşıma uygun olarak üniversite öğrencilerinin iletişim yetkinliğini değerlendirmek amacıyla KIYY'yi dört temel beceri alanına (dinleme becerisi, empati becerisi, ifade etme becerisi, sosyal rahatlama becerisi) dayalı olarak geliştirmiştir. Kişilerarası iletişim yetkinliğine sahip bireyin nitelikli bir dinleyici olması ve dinleme becerisine sahip olmas1 gerekmektedir. Dinleme becerisi, kişilerarası iletişim başarılı olabilmesi için önemli bir gerekliliği olarak değerlendirilmektedir (Bodie, 2011). Aktif dinleme, konuşanın ciddiye alındığ 1 ve dinleyicinin de konuşan kimsenin söylediklerine ilgi gösterdiği durumu temsil eden bir iletişim becerisidir (Huang ve Lin, 2018). İletişim yetkinliğinin gözlenebilmesi için gerekli olan bir diğer beceri empati becerisidir. Empati becerisi, iletişimde olunan bireylerin duygu ve düşüncelerinin içinde bulunulan duruma dayalı olarak anlamlandırılmasına olanak sağlamaktadır (Rogers, 1975). İfade etme becerisi, KIYY'nin üçüncü bileşenidir. Akıcı bir iletişim için gerekli olan ifade etme becerisi, duyguların yansıtılmasında ve kendini açma yaşantısının tam olarak karşıllk bulmasında önemli bir role sahiptir (Graham, Papa ve Brooks, 1992). KIYYE için sosyal rahatlama becerisi son bileşen olarak ele alınmıştır. Bubas (2001), sosyal etkileşimlerde sosyal rahatlamanın önemli bir davranış olduğunu belirtmektedir. Rahatlık hissi ve düşük düzeyde endişe ile karakterize edilebilen sosyal rahatlama, aşırı stres yaşamadan diğer insanların olumsuz reaksiyonlarını veya eleştirilerini yönetebilme becerisi olarak tanımlanmaktadır (Rubin ve Martin, 1994). Sonuç olarak, dört temel beceri alanını kapsayan ölçme araçlarının kişilerarası iletişim yetkinliğinin saptanmasında işlevsel olabileceği ifade edilebilir.

Alan yazın incelendiğinde, Türkiye'de iletişim becerilerinin değerlendirilmesinde çeşitli ölçme araçlarının kullanıldığı görülmektedir. İletişim Becerileri Ölçeği (Korkut-Owen ve Bugay, 2014), İletişim Becerilerini Değerlendirme Ölçeği (Korkut, 1996), Etkili İletişim Becerileri Ölçeği (Buluş, Atan ve Erten Sarıkaya, 2017), İletişim Becerileri Envanteri (Ersanlı ve Balcı, 1998) ve İletişim Yeterlilik Ölçeği (Koca ve Erigüç, 2017) iletişim temalı araştırmalarda sıklıkla kullanılan ölçme araçları arasındadır. Ancak, kişilerarası iletişim yetkinliği kavramının sahip olduğu kuramsal yapı doğrultusunda değerlendirilmesine olanak sağlayan herhangi bir ölçme aracı bulunmamaktadır. Dolayısıyla, beliren yetişkinlik dönemindeki bireylerin kişilerarası ilişkilerle ilgili sorunlarını hızlıca betimleyecek ölçme aracına yönelik ihtiyaç daha da belirginleşmektedir. Kişilerarası İletişim Yetkinliği Envanteri'nin, iletişim sürecinde yetersizliklere neden olan spesifik bileşenlerin saptanmasında ve kişilerarası iletişimin çeşitli psikososyal faktörler üzerinde etkisinin yordanmasında kullanılabilecek bir ölçme aracı olduğu düşünülmektedir.

Genel olarak değerlendirildiğinde, kişinin konuşmacıyı etkin dinleyebilmesi, sosyal çevrede rahatlayabilmesi, diğer insanlarla empati kurabilmesi ve diğer insanlarla anlamlı bir şekilde etkileşime girebilmesi onun kişilerarası iletişimde yetkin olduğunun göstergeleri olarak yorumlanmaktadır. $\mathrm{Bu}$ çalışmada, kişilerarası iletişim yetkinliğini dört temel beceri alanında (dinleme becerisi, empati becerisi, ifade etme becerisi, sosyal rahatlama becerisi) değerlendiren Kişilerarası İletişim Yetkinliği Envanteri'nin (KIYE) Türkçeye uyarlanması amaçlanmıştır. Bu amaç doğrultusunda, dört farklı aşama izlenmiştir. Birinci aşamada, KIYE'nin kaynak dilden hedef dile uyarlanması gerçekleştirilmiştir. İkinci aşamada, KIYYE'nin yapı geçerliği test edilmiştir. Üçüncü aşamada, KIYE'ye ilişkin güvenirlik ve madde analizi süreçleri tamamlanmıştır. Son olarak, dördüncü aşamada KIYE'nin ölçüt ve ayırt edici geçerliği araştırılmış ve rapor edilmiştir. 


\section{Yöntem}

\section{Çalıșma Grubu}

Araştırmanın amacı doğrultusunda dört farklı çalışma grubundan veri toplanmıştır. Birinci gruptan dil geçerliğini, ikinci gruptan yapı geçerliğini, üçüncü gruptan güvenilirlik ve madde analizini, dördüncü gruptan da ölçüt ve ayırt edici geçerliği incelemek için veri toplanmıştır.

KIYE'nin dil geçerliği kapsamında her iki dile hâkim olan bireylere ulaşılmıştır. Her iki dile hâkim olan 45 İngiliz Dili ve Edebiyatı üniversite son sınıf öğrencisi dil geçerliği çalışmasına katılmıştır. KIYE'nin kaynak ve hedef dildeki versiyonları bu öğrencilere uygulanmıştır. 33 kadın $(73.3 \%)$ ve 12 erkek $(26.7 \%)$ dil geçerliğini araştırmak için gerçekleştirilen birinci çalışmaya katılmıştır. Çalışma grubunda yer alan üniversite öğrencilerinin yaşları 18 ile 35 arasında değişmektedir. Çalışma grubunun yaş ortalaması $22.87^{\prime} \operatorname{dir}(S S=2.71)$.

Yapı geçerliği için yapılan çalışmaya gönüllülük esasına dayalı olarak, 147 kadın (\%70.7) ve 61 erkek (\%29.3) toplam 208 üniversite öğrencisi katılmıştır. Çalışma grubunu oluşturan üniversite öğrencilerinin yaşları 18 ile 30 arasında değişmektedir. Çalışma grubunun yaş ortalamas 20.70 'dir (SS = 1.66). Yapı geçerliğine yönelik sınamalar 13 (\%6.3) üniversite birinci sınıf, 59 (\%28.4) üniversite ikinci sınıf, 77 (\%37) üniversite üçüncü sınıf ve 59 (\%28.4) üniversite son sınıf öğrencisinin katılımıyla gerçekleştirilmiştir.

Güvenirlik ve madde analizi için yapılan çalışmaya 144 kadın (\%68.2) ve 67 erkek (\%29.3) toplam 211 üniversite öğrencisi katılmıştır. Çalışma grubunu oluşturan üniversite öğrencilerinin yaşları 18 ile 30 arasında değişmektedir. Çalışma grubunun yaş ortalaması 19.23'tür $(S S=1.32)$. Güvenirlik ve madde analizine yönelik değerlendirmeler 150 (\%71.1) üniversite birinci sınıf, 47 (\%22.3) üniversite ikinci sınıf, 14 (\%6.6) üniversite üçüncü sınıf öğrencisinin gönüllü katılımıyla gerçekleştirilmiştir.

Ölçüt ve ayırt edici geçerliğinin incelendiği çalışmaya 277 kadın (\%74.9) ve 93 erkek (\%25.1) toplam 370 üniversite öğrencisi katılmıştır. Çalışma grubunu oluşturan üniversite öğrencilerinin yaşları 19 ile 30 arasında değişmektedir. Çalışma grubunun yaş ortalaması 21.89 'dur $(S S=1.58)$.

\section{Veri Toplama Araçları}

$\mathrm{Bu}$ bölümde bilgileri verilen ölçme araçları araştırmada ölçüt ve ayırt edici geçerliği incelemek için kullanılmıştır.

\section{İletişim Becerileri Ölçeği (İBÖ)}

İletişim becerilerini değerlendirmek amacıyla Korkut Owen ve Bugay (2014) tarafından geliştirilmiştir. İBÖ, 25 maddeden oluşan ve öz-bildirime dayalı beşli likert tipi değerlendirmeye sahip bir ölçme aracıdır. Açımlayıcı faktör analizi sonuçlarına göre dört faktörlü yapı toplam varyansın \%45.93'ünü açıklamaktadır. Doğrulayıcı faktör analizi sonuçlarına göre dört faktörlü yapı verilerle iyi düzeyde uyum göstermektedir $(R M S E A=.046, T L I=.90, C F I=.91, S R M R=.068)$. İBÖ'nün güvenirliği Cronbach Alpha iç tutarlık katsayısı ile değerlendirilmiştir $(\alpha=.88)$. Sonuç olarak, İBÖ'nün geçerli ve güvenilir bir ölçme aracı olduğu ifade edilebilir. Bu çalışma kapsamında, İBÖ'nün iç tutarlık katsayısı .88 olarak belirlenmiştir.

\section{Kısaltılmış Proaktif Kişilik Ölçeği (KPKÖ).}

Proaktif kişilik eğilimlerinin belirlenmesi amacıyla Bateman ve Crant (1993) tarafindan geliştirilmiştir. KPKÖ'nün Türkçeye adaptasyon çalışması Akın ve Özcan (2015) tarafından gerçekleştirilmiştir. KPKÖ, 10 maddeden oluşan ve öz-bildirime dayalı yedili likert tipi değerlendirmeye sahip ölçme aracıdır. Doğrulayıcı faktör analizi sonuçlarına göre tek faktörlü yapı verilerle iyi düzeyde uyum göstermektedir $(R M S E A=.044, N F I=.99, C F I=.99, S R M R=.033)$. 
KPKÖ’nün güvenirliği Cronbach Alpha iç tutarlık katsayısı ile değerlendirilmiştir $(\alpha=.86)$. Sonuç olarak, KPKÖ’nün geçerli ve güvenilir bir ölçme aracı olduğu ifade edilebilir. Bu çalışma kapsamında, KPKÖ'nün iç tutarlık katsayısı .85 olarak belirlenmiştir.

\section{Genel Öz-Yeterlik Ölçeği (GÖYÖ)}

Bireylerin öz-yeterlik algılarını genel bir perspektifte değerlendirmek amacıyla Schwarzer ve Jerusalem (1979) tarafından geliştirilmiştir. GÖYÖ'nün Tükçe adaptasyon çalışması Aypay (2010) tarafından gerçekleştirilmiştir. GÖYÖ, iki boyutta toplam 10 maddeden oluşan ve öz-bildirime dayalı dörtlü likert tipi değerlendirmeye sahip ölçme aracıdır. GÖYÖ'nün güvenirliği Cronbach Alpha iç tutarlık katsayısı ile değerlendirilmiştir $(\alpha=.83)$. Sonuç olarak, GÖYÖ'nün geçerli ve güvenilir bir ölçme aracı olduğu ifade edilebilir. Bu çalışma kapsamında, KPKÖ'nün iç tutarlık katsayısı .88 olarak belirlenmiştir.

\section{Pozitiflik Ölçeği (PÖ)}

Bireylerin pozitiflik düzeylerini değerlendirmek amacıyla Caprara ve ark. (2012) tarafından geliştirilmiştir. PÖ'nün Türkçe adaptasyon çalışması Çıkrıkçı, Çiftçi ve Gençdoğan (2015) tarafından gerçekleştirilmiştir. PÖ, 8 maddeden oluşan ve öz-bildirime dayalı beşli likert tipi değerlendirmeye sahip bir ölçme aracıdır. Doğrulayıcı faktör analizi sonuçlarına göre tek faktörlü yapı verilerle iyi düzeyde uyum göstermektedir $(R M S E A=.06, C F I=.95, S R M R=.04)$. PÖ'nün güvenirliği Cronbach Alpha iç tutarlık katsayısı ile değerlendirilmiştir $(\alpha=.73)$. Sonuç olarak, PÖ’nün geçerli ve güvenilir bir ölçme aracı olduğu ifade edilebilir. Bu çalışma kapsamında, PÖ'nün iç tutarlık katsayısı .80 olarak belirlenmiştir.

\section{İşlem Basamakları}

KIYYE'nin dil geçerliği için maddelerin geri çevirisinin tamamlanması ve kaynak-hedef dil versiyonlarının her iki dile hâkim bireylere uygulanması amaçlanmıştır. Kişilerarası İletişim Yetkinliği Envanteri'nin dil geçerliği kapsamında öncelikle geri çeviri yöntemi benimsenmiş̧ir (Brislin, 1970). Geri çeviri aşamasında, KIYYE kaynak dilden (İngilizce) hedef dile (Türkçe) iki çevirmen tarafından uyarlanmıştır. Daha sonra bu çevirmenlerden farklı iki çevirmen de ölçme aracını oluşturan maddeleri hedef dilden (Türkçe) kaynak dile (İngilizce) çevirmiştir. Orijinal ve geri çevirisi yapılmış yapılar karşılaştırılmış ve iki durumun orijinal forma denkliği araştırılmıştır (Hambleton, 2005). Kaynak dilden hedef dile uyarlanan maddeler anlaşılabilirlik açısından hedef dil uzmanları tarafından değerlendirilmiştir. Bu aşamadan sonra, KIYE maddelerinin (hedef dilde), içeriği kapsama durumu alan uzmanları tarafından gerçekleştirilmiştir. Son olarak, her iki dile hâkim olan bireylere kaynak form ve hedef form uygulanmıştır. Aynı bireylerden elde edilen ölçümlere dayalı olarak ölçme aracının dil geçerliği araştırılmıştır.

KIYE'nin yapı geçerliğini test etmek amacıyla madde analizi ve doğrulayıcı faktör analizi süreçleri takip edilmiştir. Huang ve Lin (2018), KIYE'nin faktör yapısını incelemiş ve dört faktörlü yapının verilerle iyi düzeyde uyum gösterdiğini rapor etmiştir. Daha önce belirlenmiş olan dört faktörlü yapının (kaynak dilde; İngilizce) hedef dildeki (Türkçe) uygunluğunu değerlendirmek amacıyla doğrulayıcı faktör analizinin uygulanmasına karar verilmiştir. Yapı geçerliği kapsamında ilk olarak KIYYE'de yer alan maddelerin birbirleriyle ve bütün yapı ile tutarlığı madde analizi süreciyle araştırılmıştır. Madde-toplam korelasyonları incelenerek madde analizi süreci tamamlanmıştır. KIYE'yi oluşturan maddelerin kendi aralarında tutarlı olduğuna karar vermek için madde-toplam korelasyonlarının .30 ve üzeri olması ölçüt olarak kabul edilmiştir. Madde analizi sürecinden sonra doğrulayıcı faktör analizi gerçekleştirilmiş ve dört faktörlü yapı test edilmiştir. Kuramsal bir çıkarıma dayalı olarak belirlenen faktörlerin gerçek verilerle tutarlığını değerlendirmek için doğrulayıcı faktör analizinin uygulanması önerilmektedir (Kline, 2016). Doğrulayıcı faktör analizinin sonuçları bazı uyum indekslerine dayalı olarak değerlendirilmektedir. Bu çalışmada, model uyumu değerlendirilirken Root Mean Square Error of Approximation (RMSEA), Tucker-Lewis Index (TLI), Comparative Fit Indices (CFI), Goodness of Fit Index (GFI) ve Standardized Root Mean Square Residual (SRMR) 
uyum indekslerinden yararlanılmıştır. Bununla birlikte, doğrulayıcı faktör analizi ile sınanan modeller arasında karşılaştırma yapabilmek amacıyla Akaike's Information Criterion (AIC) ve The Expected Cross-validation Index (ECVI) uyum göstergeleri incelenmiştir.

Ölçme araçlarının bilimsel araştırmalarda kullanılabilmesi için geçerli ve güvenilir olmaları gerekmektedir. KİYE'nin orijinal formunun güvenilir olduğu Huang ve Lin (2018) tarafindan rapor edilmiştir (Cronbach'a Alpha $=.84$ ). Araştırmanın üçüncü aşamasında KIYYE'nin hedef dildeki (Türkçe) güvenirliğinin belirlenmesi ve KIYYE'ye ilişkin madde analizinin yeniden gerçekleştirilmesi amaçlanmıştır. KIYE'nin bütününe ve alt faktörlerine ilişkin iç tutarlık katsayıları Cronbach Alpha $(\alpha)$ ve McDonald Omega $(\omega)$ güvenirlik katsayıları aracılığıyla incelenmiştir. Her iki güvenirlik katsayısı için .70 ve üzeri değerler ölçüt kabul edilmiştir.

Kişilerarası İletişim Yetkinliği Envanteri'nin ölçüt geçerliğini belirlemek amaciyla İletişim Becerileri Ölçeği toplam puanı ile Kişilerarası İletişi Yetkinliği Envanteri toplam puanı arasındaki ilişkiler Pearson Momentler Çarpımı Korelasyon Katsayısı tekniği ile incelenmiştir. Ayırt edici geçerlik kapsamında, kişilerarası iletişim yetkinliği, proaktif kişilik ve genel öz-yeterlik pozitifliğin yordayıcıları olarak değerlendirilmiştir. Kişilerarası iletişim yetkinliğinin pozitiflik üzerindeki özgün yordayıcılığı hiyerarşik regresyon analizi ile belirlenmiştir.

\section{Etik Prosedürler}

$\mathrm{Bu}$ araştırmanın tüm aşamalarında bir takım etik kurallar benimsenmiştir (American Educational Research Association [AERA], 2011; American Psychological Association [APA], 2020). Amerikan Psikoloji Birliği (APA) tarafından önerilen etik prosedürler özenle takip edilmiştir. Aynı zamanda, araştırmanın etik açıdan uygunluğu ikinci yazarın görev yaptığı üniversitenin Sosyal ve Beşeri Bilimler Etik Kurulu tarafından onaylanmıştır (29.09.2020; Karar No: 2020-75). Katılımcılar gönüllülük ilkesi doğrultusunda çalışmaya dâhil olmuş ve katılımcılardan onay alınmıştır. Katılımcıları tanımlayacak nitelikte bilgi (ad, soyad vb.) talep edilmemiştir. Katılımcılardan kendileri için bir rumuz (takma ad) oluşturmaları istenmiş̧ir. Kişisel mahremiyet ile birlikte katılımcıların itibarı ve hakları güvence altına alınmıştır. Katılımcılara, bir sebep belirtmeksizin araştırmanın herhangi bir aşamasında çalışmadan çekilebilecekleri bilgisi sunulmuştur. Araştırmacılar, analiz ve raporlama sürecinde şeffaflık ilkesini titizlikle benimsemiştir. Son olarak, benimsenen yayın etiğinin bir yansıması olarak da araştırmacılar sorumlu ve nitelikli bir çalışma gerçekleştirmiştir.

\section{Bulgular}

\section{Dil Geçerliği}

KIYE'nin dil geçerliğini istatistiksel olarak saptamak amacıyla hedef ve kaynak dile ilişkin ölçümler karşılaştırılmıştır. Her iki dile ilişkin ölçümlerin karşılaştırılmasına geçilmeden önce verilerin normallik varsayımı test edilmiş ve her iki ölçümün Shapiro-Wilk değerleri incelenmiştir. Normallik varsayımı analizi sonuçlarına göre, KİYE’nin İngilizce $\left(S-W_{(45)}=.10, p=.200\right)$ ve Türkçe formu $\left(S-W_{(45)}=.08, p=.200\right)$ normallik varsayımını karşılamaktadır. Dolayısıyla, her iki dile ilişkin ölçümlerin karşılaştırılmasında parametrik tekniklerden bağımlı grup t testi uygulanmıştır. Bağımlı grup $t$ testi sonuçlarına göre KIYYE'ye ilişkin Türkçe ve İngilizce ölçümler arasında istatistiksel açıdan anlamlı bir farklılık bulunmamaktadır $\left(t{ }_{(44)}=.126, p>.05\right)$. KIYYE'yi oluşturan maddelere ilişkin gerçekleştirilen analiz sonucunda, her bir maddenin Türkçe ve İngilizce ölçümü arasında anlamlı bir farklılık bulunmamaktadır. Elde edilen bulgular doğrultusunda, KIYYE’nin dil geçerliğini sağladığı ifade edilebilir.

\section{Yapı Geçerliği}

Madde analizi kapsamında madde-toplam korelasyonları incelenmiştir. KIYYE için maddetoplam korelasyonları .30 ile .59 arasında değişmektedir. Bu bulgu doğrultusunda, ölçme aracını 
oluşturan maddelerin toplam yapı ile tutarlılık gösterdiğine ve ileri analizlere KIYYE'yi oluşturan tüm maddelerle devam edilmesine karar verilmiştir (Tablo 1).

Tablo 1.

Kişilerarası İletişim Yetkinliği Envanteri Madde Analizi Sonuçları

\begin{tabular}{|c|c|c|c|c|}
\hline Madde & $\begin{array}{c}\text { Madde silinirse } \\
\text { ortalama }\end{array}$ & $\begin{array}{c}\text { Madde silinirse } \\
\text { varyans }\end{array}$ & $\begin{array}{c}\text { Düzeltilmiş } \\
\text { madde-toplam } \\
\text { korelasyonu }\end{array}$ & $\begin{array}{l}\text { Madde silinirse } \\
\text { Cronbach Alpha }\end{array}$ \\
\hline KIYE_m1 & 54.80 & 40.60 & .50 & .791 \\
\hline KIYE_m2 & 54.96 & 41.33 & .40 & .797 \\
\hline KIYE_m3 & 55.14 & 39.81 & .59 & .786 \\
\hline KIYE_m4 & 55.20 & 39.92 & .49 & .791 \\
\hline KIYE_m5 & 55.48 & 41.05 & .32 & .803 \\
\hline KIYE_m6 & 55.60 & 40.44 & .34 & .802 \\
\hline KIYY_m7 & 55.42 & 41.21 & .29 & .805 \\
\hline KIYE_m8 & 55.77 & 40.11 & .39 & .798 \\
\hline KIYYE_m9 & 55.57 & 39.35 & .44 & .794 \\
\hline KIYYE_m10 & 55.32 & 41.10 & .30 & .807 \\
\hline KIYYE_m11 & 55.56 & 39.65 & .38 & .799 \\
\hline KIYE_m12 & 55.16 & 39.81 & .57 & .787 \\
\hline KIYYE_m13 & 55.90 & 40.21 & .36 & .800 \\
\hline KIYYE_m14 & 55.40 & 39.584 & .594 & .785 \\
\hline KIYYE_m15 & 55.44 & 40.161 & .429 & .795 \\
\hline
\end{tabular}

Not. Cronbach Alpha $=.81 ;$ McDonald Omega $=.82$

Madde analizinden sonra, dört faktörlü KIYYE’nin Türk kültüründeki uygunluğu doğrulayıcı faktör analizi ile incelenmiştir. Standartlaştırılmış faktör yükleri, standart hatalar, t değerleri ve R2 değerleri Tablo 2'de sunulmuştur.

Tablo 2 .

Kişilerarası İletișim Yetkinliği Envanteri'nin Maddelerine İlișkin Tanımlayıcı İstatistikler

\begin{tabular}{lllllc}
\hline Faktör & Madde & $\boldsymbol{\lambda}$ & $\mathbf{t}$ & $\mathbf{R}^{\mathbf{2}}$ & Hata varyansi \\
\hline Dinleme & Madde 1 & .63 & $8.55^{* *}$ & .40 & .60 \\
Becerisi & Madde 2 & .55 & $9.12^{* *}$ & .30 & .69 \\
& Madde 3 & .68 & $8.05^{* *}$ & .46 & .53 \\
& Madde 4 & .54 & $9.19^{* * *}$ & .29 & .70 \\
\hline Sosyal & Madde 5 & .52 & $8.24^{* *}$ & .73 & .28 \\
Rahatlık & Madde 6 & .57 & $7.75^{* *}$ & .67 & .33 \\
Becerisi & Madde 7 & .34 & $9.43^{* *}$ & .88 & .12 \\
& Madde 8 & .59 & $7.48^{* *}$ & .65 & .35 \\
\hline Empati & Madde 9 & .53 & $9.02^{* *}$ & .71 & .29 \\
Becerisi & Madde 10 & .36 & $9.72^{* *}$ & .87 & .13 \\
& Madde 11 & .55 & $8.96^{* *}$ & .69 & .30 \\
& Madde 12 & .78 & $5.46^{* * *}$ & .39 & .24 \\
\hline İfade & Madde 13 & .49 & $9.23^{* *}$ & .76 & .56 \\
Becerisi & Madde 14 & .75 & $5.82^{* *}$ & .43 & .27 \\
& Madde 15 & .51 & $9.10^{* *}$ & .74 & \\
\hline$\lambda=$ S & & & &
\end{tabular}

$\lambda=$ Standartlaştırılmış Faktör Yükü

Tablo 2'de görüldüğg̈ gibi standartlaştırılmış faktör yükleri $\lambda=.34$ ile $\lambda=.78$ arasında değişmektedir ve $t$ değerlerinin tamamı anlamlıdır $(p<.01)$. Doğrulayıcı faktör analizi sürecinde dört farklı model test edilmiştir. Birinci model (hipotez model) birinci düzey doğrulayıcı faktör analizi 
olarak adlandırılan yapıyı kapsamaktadır. Başka bir ifadeyle hipotez model KIYE'nin faktörleri arasında kovaryansların olduğuna ilişkin bir yapıyı temsil etmektedir. İkinci model (model a), KIYE'yi oluşturan tüm maddelerin tek bir yapı altında toplandığına ilişkin varsayımı kapsamaktadır. Üçüncü model (model b), ikinci düzey doğrulayıcı faktör analizi olarak ifade edilebilecek bir yapıyı göstermektedir. Model b, KIYE'yi oluşturan alt faktörlerin tek bir yapı ile ilişkisini kapsamaktadır. Dördüncü model, iki faktör (bi-factor) modeli temsil etmektedir. Dördüncü modelde, KIYYE maddelerinin hem tek bir yapı altında hem de ilgili faktörler altında yer almaları durumu test edilmiştir (Şekil 1).

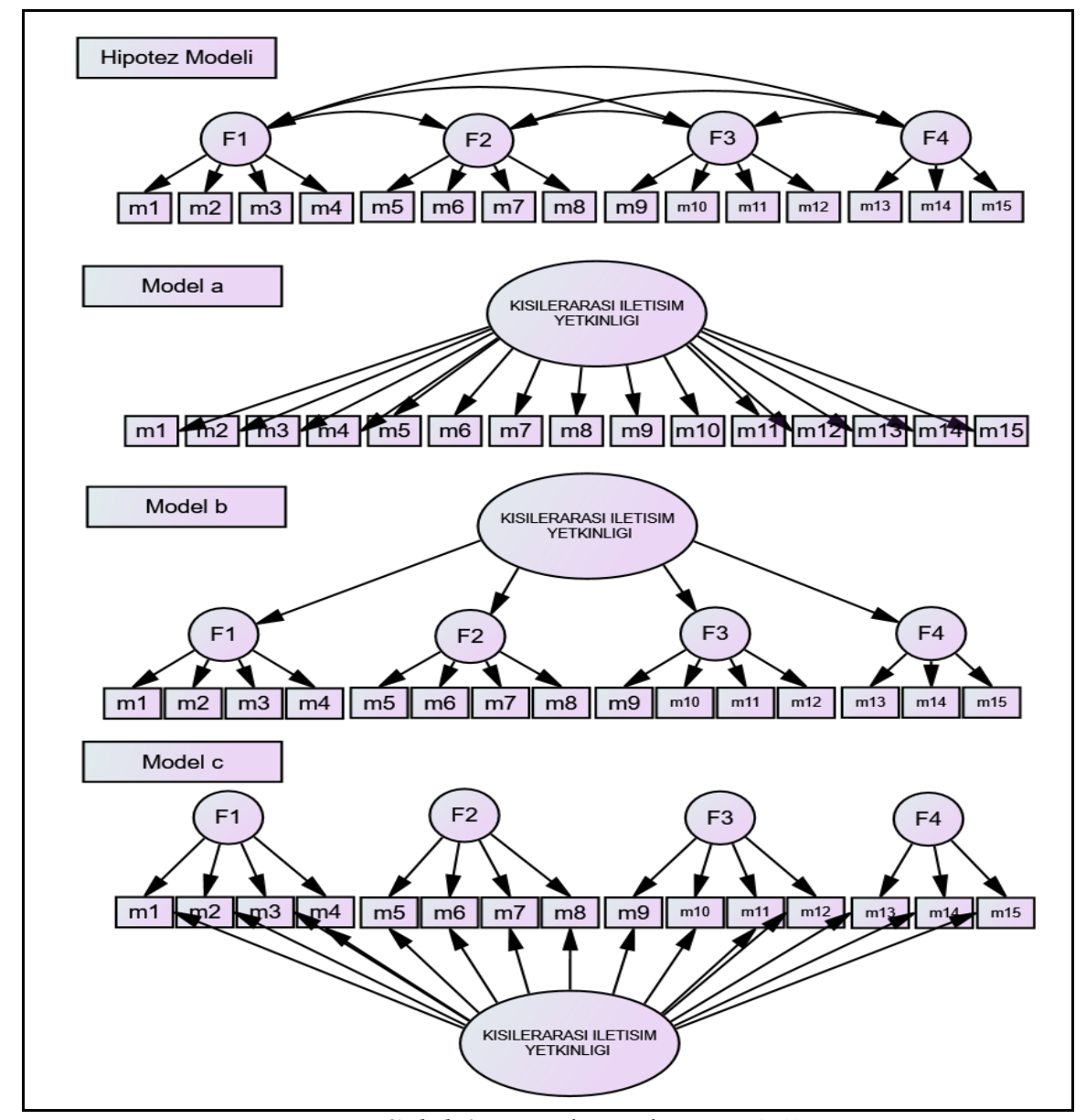

Şekil 1. Karşılaştırılan Modeller

Not. F1 = Dinleme Becerisi, F2 = Sosyal Rahatlık Becerisi, F3 = Empati Becerisi, F4 = İfade Becerisi

Yapılan analizler doğrultusunda dört model değerlendirilmiştir. Buna göre, ikinci (model a) ve üçüncü modelin (model b) uyum indekslerinin ölçütleri karşılamadığı sonucuna ulaşılmıştır. Birinci (hipotez model) ve dördüncü (iki faktör model) modelin verilerle iyi düzeyde uyum gösterdiği belirlenmiştir. Bu modeller arasında hangi modelin daha uygun olduğuna karar vermek amaciyla AIC ve ECVI değerleri incelenmiştir. Yapılan değerlendirme sonrasında birinci modelin (hipotez modelin) daha düşük AIC ve ECVI değerlerine sahip olduğu gözlenmiştir $\left(\mathrm{x}^{2} / \mathrm{sd}=1.59\right.$, RMSEA $=.054 \% 90 \mathrm{CI}$ $[.036, .070], T L I=.91, C F I=.93, G F I=.92, S R M R=.05 ; A I C=206.65, E C V I=1.0090 \%$ CI [.868, 1.170]). Test edilen tüm modellere ilişkin uyum indeksleri Tablo 3 'te sunulmuştur.

Tablo 3 .

Doğrulayıcı Faktör Analizinden Elde Edilen Uyum İndekslerinin Özeti

\begin{tabular}{|c|c|c|c|c|c|c|c|c|c|c|}
\hline Model & $\mathrm{x}^{2}$ & sd & $\mathrm{x}^{2} / \mathrm{sd}$ & RMSEA & TLI & CFI & GFI & SRMR & AIC & ECVI \\
\hline $\begin{array}{l}\text { Ölçüt } \\
\text { değerler }\end{array}$ & ב-..- & $\ldots-$ & $<3$ & $<.08$ & $>.90$ & $>.90$ & $\begin{array}{l}>.9 \\
0\end{array}$ & $<.08$ & ...- & $\ldots$ \\
\hline $\begin{array}{l}\text { Hipotez } \\
\text { modeli }\end{array}$ & 130.95 & 82 & 1.59 & $\begin{array}{l}.054 \\
{[.036, .070]}\end{array}$ & .91 & .93 & .92 & .05 & 206.95 & $\begin{array}{l}1.00(90 \% \mathrm{CI} \\
[.868,1.170])\end{array}$ \\
\hline
\end{tabular}




\begin{tabular}{|c|c|c|c|c|c|c|c|c|c|c|}
\hline $\begin{array}{l}\text { Birinci } \\
\text { Model } \\
\text { (Model a) }\end{array}$ & 269.93 & 88 & 2.99 & $\begin{array}{l}.098 \\
{[.085, .112]}\end{array}$ & .70 & .74 & .83 & .09 & 219.82 & $\begin{array}{l}1.06(90 \% \mathrm{CI} \\
[.919,1.242])\end{array}$ \\
\hline $\begin{array}{l}\text { İkinci } \\
\text { Model } \\
\text { (Model b) }\end{array}$ & 207.57 & 88 & 2.36 & $\begin{array}{l}.08 \\
{[.067, .095]}\end{array}$ & .80 & .83 & .87 & .08 & 271.57 & $\begin{array}{l}1.31(90 \% \mathrm{CI} \\
{[1.127,} \\
1.534])\end{array}$ \\
\hline $\begin{array}{l}\text { Üçüncü } \\
\text { Model } \\
\text { (Model c) }\end{array}$ & 124.84 & 73 & 1.71 & $\begin{array}{l}.059 \\
{[.041, .076]}\end{array}$ & .89 & .92 & .92 & .05 & 218.84 & $\begin{array}{l}1.057(90 \% \mathrm{CI} \\
[.927,1.226])\end{array}$ \\
\hline
\end{tabular}

Not. ${ }^{* *} p<.01$. Düşük AIC ve ECVI değerleri daha iyi uyumu göstermektedir.

Sonuç olarak hipotez model kabul edilmiş ve ileri analizler hipotez modeldeki yapıya uygun olarak gerçekleştirilmiş̧tir. KİYE’nin doğrulayıcı faktör analizine (hipotez model) ilişkin path diagramı Şekil 2'de sunulmuştur.

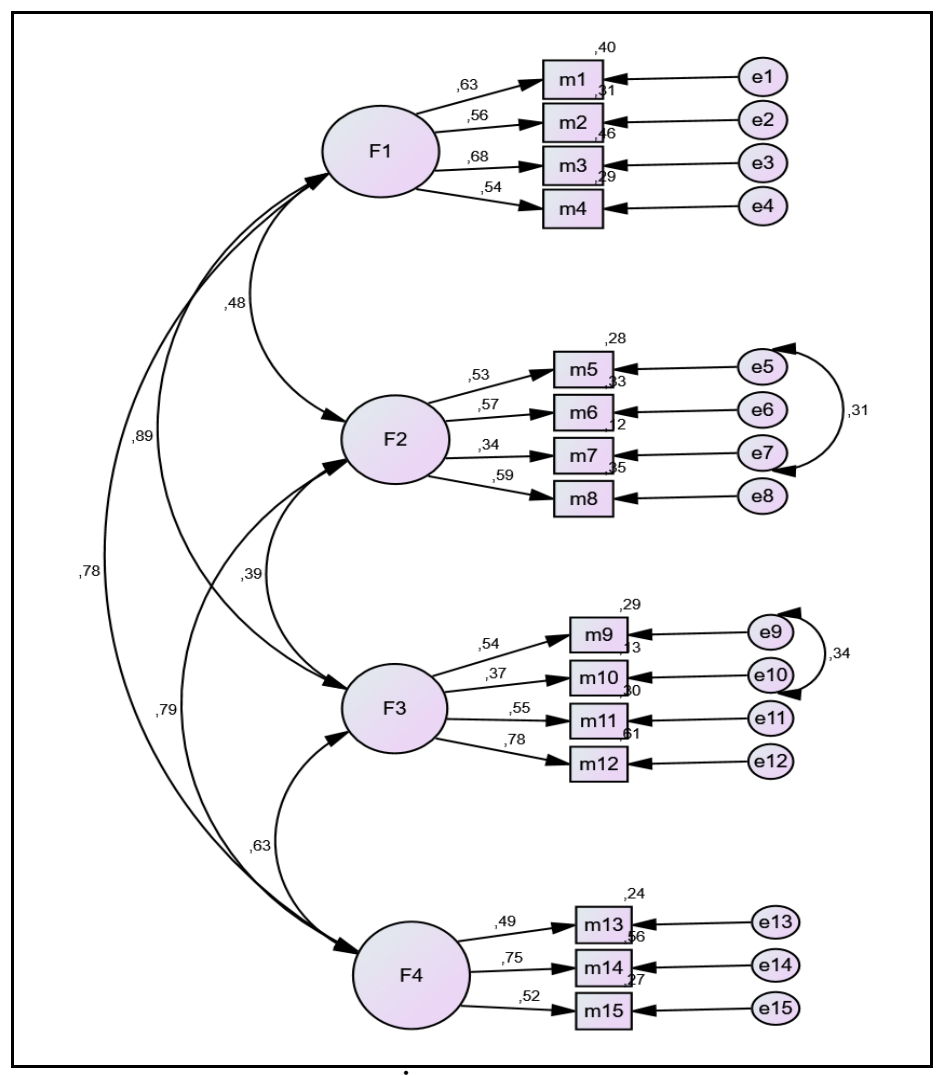

Şekil 2. KIYE Path Diagramı

Not. F1 = Dinleme Becerisi, F2 = Sosyal Rahatllk Becerisi, F3 = Empati Becerisi, F4 = İfade Becerisi

\section{Güvenirlik ve Madde Analizi}

Kişilerarası İletişim Yetkinliği Envanterine ilişkin güvenirlik analizi bulguları Tablo 4'te sunulmuştur. Elde edilen bulgulara göre KIYE güvenilir bir ölçme aracıdır $(\alpha=.78 ; \omega=.80)$. KIYYE'nin alt boyutlarının iç tutarlık katsayıları ölçüt olarak Kabul edilen .70 değerinin üzerindedir (Dinleme Becerisi $[\alpha=.73 ; \omega=.73]$; Sosyal Rahatlık Becerisi $[\alpha=.71 ; \omega=.73]$; Empati Becerisi $[\alpha=$ $.76 ; \omega=.78]$, İfade Becerisi $[\alpha=.78 ; \omega=.80])$. Dolayısıyla, alt faktörlerin de güvenilir bir yapıya sahip olduğu ifade edilebilir.

Tablo 4.

Güvenirlik, Ortalamalar, Standart Sapmalar, Alt Faktörler Arasındaki Korelasyonlar

\begin{tabular}{|c|c|c|c|c|c|c|c|c|c|c|c|}
\hline \multirow[t]{2}{*}{ Ölçek } & \multirow[b]{2}{*}{$\boldsymbol{\alpha}$} & \multirow[b]{2}{*}{$\omega$} & \multicolumn{2}{|c|}{ Ranj } & \multirow[t]{2}{*}{$\mathbf{X}$} & \multirow[t]{2}{*}{ SS } & \multicolumn{5}{|c|}{ Korelasyonlar } \\
\hline & & & Min. & Max. & & & 1 & 2 & 3 & 4 & 5 \\
\hline
\end{tabular}




\begin{tabular}{|c|c|c|c|c|c|c|c|c|c|c|c|}
\hline DB (1) & .73 & .73 & 11.00 & 20.00 & 17.06 & 2.12 & 1 & & & & \\
\hline SRB (2) & .71 & .73 & 7.00 & 20.00 & 14.54 & 2.86 & $.336^{* *}$ & 1 & & & \\
\hline EB (3) & .76 & .78 & 9.00 & 20.00 & 15.91 & 2.58 & $.447^{* *}$ & $.268^{* *}$ & 1 & & \\
\hline İB (4) & .78 & .80 & 4.00 & 15.00 & 10.83 & 2.15 & $.316^{* *}$ & $.314^{* *}$ & $.231^{* *}$ & 1 & \\
\hline KIY (5) & .78 & .80 & 40.00 & 74.00 & 58.35 & 6.81 & $.723^{* *}$ & $.727^{* *}$ & $.705^{* *}$ & $.635^{* * *}$ & 1 \\
\hline
\end{tabular}

Not. ${ }^{* *} \mathrm{p}<.01$; KIY $=$ Kişilerarası İletişim Yetkinliği; DB = Dinleme Becerisi, SRB = Sosyal Rahatlık Becerisi, EB = Empati Becerisi, İB = İfade Becerisi

Güvenirlik analizinin ardından Kişilerarası İletişim Yetkinliği Envanteri'ni oluşturan maddelerin ölçme aracının tamamı ile tutarlığını belirlemek için tekrar madde analizi yapılmıştır. Madde analizi sürecinde iki farklı uygulama yapılmıştır. Birinci uygulamada, bağımsız gruplar $\mathrm{t}$ testi uygulanmış ve \%27'lik alt-üst gruplara ilişkin toplam puanlar arasında anlamlı farklılık olduğu belirlenmiştir. İkinci uygulamada, madde toplam korelasyonlarına incelenmiş ve madde toplam korelasyon katsayılarının .38 ile .60 arasında değişkenlik gösterdiği belirlenmiştir (Tablo 5).

Tablo 5 .

Madde Toplam Korelasyonları, \%27'lik Alt-Üst Gruplar Arasındaki Farklıllklar

\begin{tabular}{|c|c|c|}
\hline Madde & $\mathbf{r}_{\mathrm{tt}}$ & $\mathbf{t}$ \\
\hline KIYY $\mathrm{m} 1$ & $.45^{* *}$ & $6.88^{* * * *}$ \\
\hline KIYE m2 & $.58^{* *}$ & $10.60^{\text {**** }}$ \\
\hline KIYE-m3 & $.52^{* *}$ & $7.91^{\text {**** }}$ \\
\hline KIYE $\mathrm{m} 4$ & $.58^{* *}$ & $8.07^{* * * *}$ \\
\hline KIYE_m5 & $.52^{* *}$ & $8.00^{* * *}$ \\
\hline KIYE $\mathrm{m} 6$ & $.49^{* *}$ & $7.87^{* * * *}$ \\
\hline KIYE_m7 & $.47^{* *}$ & $6.56^{* * *}$ \\
\hline KIYE $\mathrm{m} 8$ & $.53^{* *}$ & $7.23^{* * *}$ \\
\hline KIYE_m9 & $.47^{* *}$ & $6.62^{2 * *}$ \\
\hline KIYY $\mathrm{m} 10$ & $.46^{* *}$ & $7.41^{* * * *}$ \\
\hline KIYE $\mathrm{m} 11$ & $.49^{* *}$ & $6.90^{* * * *}$ \\
\hline KIYE $\mathrm{m} 12$ & $.60^{* *}$ & $10.29^{\text {**** }}$ \\
\hline KIYE $\mathrm{m} 13$ & $.40^{* *}$ & $5.42^{* * * *}$ \\
\hline KIYYE-m14 & $.59^{* *}$ & $9.42^{* * *}$ \\
\hline KIYY ${ }^{-} 15$ & $.38^{* *}$ & $5.78^{* * *}$ \\
\hline
\end{tabular}

${ }^{* * * *} p<.001,{ }^{* * *} p<.01 ; r_{t t}:$ Düzeltilmiş Madde Toplam Korelasyon Katsaylsl

\section{Ölçüt ve Ayırt Edici Geçerlik}

\section{Ölçüt Geçerliği}

Ölçüt bağıntılı geçerlik kapsamında Kişilerarası İletişim Yetkinliği Değerlendirme Envanteri ve İletişim Becerileri Ölçeği toplam puanları arasındaki ilişkiler incelenmiştir (Tablo 6). Korelasyon analizi sonucuna göre Kişilerarası İletişim Yetkinliği Envanteri toplam puanları ile İletişim Becerileri Ölçeği toplam puanları arasında pozitif yönde anlamlı ilişki bulunmaktadır $(r=.78, p<.01 ; \% 95 \mathrm{CI}=$ $.73, .82)$. Buna göre Kişilerarası İletişim Yetkinliği Envanteri’nin ölçüt bağıntılı geçerliği sağladığı ifade edilebilir.

Tablo 6.

Kişilerarası İletişim Yetkinliği ve İletişim Becerileri Arasındaki İlişkiler

\begin{tabular}{lll}
\hline Değişkenler & $\mathbf{1}$ & $\mathbf{2}$ \\
\hline KiY $(1)$ & 1 & 1 \\
İB $(2)$ & $.78^{* *}$ & 104.95 \\
\hline Ortalama & 61.59 & 10.21 \\
Standart Sapma & 6.27 & .88 \\
Cronbach Alpha & .75 & ${ }^{* *} \mathrm{p}<.01 ;$ KİY $=$ Kişilerarası İletişim Yetkinliği, İB = İletişìm Becerileri
\end{tabular}




\section{Ayırt Edici Geçerlik}

Ayırt edici geçerlik kapsamında Kişilerarası İletişim Yetkinliği Envanteri toplam puanları ile Kısaltılmış Proaktif Kişilik Ölçeği, Genel Öz-yeterlik Ölçeği ve Pozitiflik Ölçeği toplam puanları arasındaki ilişkiler incelenmiştir. Buna göre, kişiler arası iletişim yetkinliği ile proaktif kişilik $(r=.37$, $p<.01 ; \% 95 \mathrm{CI}=.26, .47)$, öz-yeterlik $(r=.40, p<.01 ; \% 95 \mathrm{CI}=.29, .50)$ ve pozitiflik $(r=.39, p<.01$; $\% 95 \mathrm{CI}=.28, .49)$ arasında anlamlı ilişkiler bulunmaktadır. Kişilerarası İletişim Yetkinliği Envanteri'nin ayırt ediciliğini saptamak amacıyla proaktif kişilik, öz-yeterlik ve kişilerarası iletişim yetkinliğinin pozitifliği yordama gücü hiyerarşik regresyon analizi ile değerlendirilmiştir (Tablo 7). Regresyon analizinin gerçekleştirilebilmesi için gerekli olan varsayımların karşılandığı görülmüştür. Buna göre, oto korelasyon durumunun değerlendirilmesine olanak sağlayan Durbin-Watson değeri (1.58) kabul edilebilir sınırlar (1.5-2.5) arasındadır (Field, 2013). Değişkenler tarafından açılanamayan varyans oranına vurgu yapan tolerans değeri $\left(1-R^{2}\right)$ ve varyans büyütme faktörü (VIF) ayrıca incelenmiştir. İnceleme sonucunda, elde edilen değerlerin $\left(1-\mathrm{R}^{2}=.55-.99 ; \mathrm{VIF}=1.006-1.800\right)$ kabul edilebilir sınırlar $\left(1-\mathrm{R}^{2}=>.20 ; \mathrm{VIF}=<10\right)$ arasında olduğu sonucuna ulaşılmıştır (Field, 2013).

Tablo 7.

Hiyerarșik Regresyon Model Özeti

\begin{tabular}{|c|c|c|c|c|c|c|c|c|c|}
\hline \multirow[t]{2}{*}{ Model } & \multirow[t]{2}{*}{$\mathbf{R}$} & \multirow[t]{2}{*}{$\mathbf{R}^{2}$} & \multirow[t]{2}{*}{ TSH } & \multicolumn{5}{|c|}{ Değişim İstatistikleri } & \multirow{2}{*}{$\begin{array}{l}\text { Durbin- } \\
\text { Watson }\end{array}$} \\
\hline & & & & $\Delta \mathbf{R}^{2}$ & $\Delta \mathbf{F}$ & sd $_{1}$ & $\mathbf{s d}_{2}$ & $\mathbf{p}$ & \\
\hline Model 1 & .46 & .21 & 4.62 & .20 & 24.50 & 4 & 365 & $<.001$ & 1.58 \\
\hline Model 2 & .51 & .26 & 4.48 & .25 & 25.64 & 5 & 364 & $<.001$ & \\
\hline
\end{tabular}

Not. TSH $=$ Tahmini Standart Hata, $\mathrm{sd}=$ Serbestlik Derecesi

Kişilerarası İletişim Yetkinliği Envanteri'nin ayırt edici geçerliği kapsamında pozitiflik bağımlı değişken, yaş, cinsiyet, proaktif kişilik, öz-yeterlik ve kişiler arası iletişim yetkinliği bağımsız değişkenler olarak belirlenmiştir. Bağımsız değişkenlerin bağımlı değişkeni yordama gücü hiyerarşik regresyon analizine uygun formatta enter metodu kullanılarak iki adımda gerçekleştirilmiştir. Birinci adımda yaş ve cinsiyet ile birlikte proaktif kişilik ve öz-yeterliğin pozitifliği yordama gücü araştırılmıştır. Regresyon analizi bulguları, proaktif kişilik ile öz-yeterliğin pozitifliğin anlamlı birer yordayıcısı olduklarını göstermektedir $\left(F_{(4,365)}=24.50, p<.001\right)$. Aynı zamanda, proaktif kişilik $(\beta=$ $.30, p<.001, \% 95 \mathrm{CI}=.11, .29)$ ile öz-yeterliğin $(\beta=.20, p<.001, \% 95 \mathrm{CI}=.07, .34)$ modele katkıs1 anlamlı bulunmuştur. Birinci adımda yer alan değişkenler pozitiflik toplam varyansının \%20'sini açıklamaktadır. İkinci adımda kişilerarası iletişim yetkinliği modele dâhil edilmiş ve analiz yeniden gerçekleştirilmiştir. Buna göre, proaktif kişilik $(\beta=.26, p<.001, \% 95 \mathrm{CI}=.08, .27)$ ve kişilerarası iletişim yetkinliği $(\beta=.25, p<.001, \% 95 \mathrm{CI}=.12, .29)$ pozitifliğin anlamlı yordayıc1larıdır $\left(F_{(5,364)}=\right.$ $25.64, p<.001)$. Öz-yeterliğin modele katkısı anlamsız bulunmuştur $(\beta=.12, p<.001, \% 95 \mathrm{CI}=-.01$, .25). Bu model pozitiflik toplam varyansının \%25'ini açıklamaktadır (Tablo 8). Hiyerarşik regresyon model özeti değerlendirildiğinde, kişilerarası iletişim yetkinliğinin pozitifliğin açıklanmasında önemli katkısının olduğu $\left(\mathrm{R}^{2}\right.$ değişim $\left.=\% 5\right)$ sonucuna ulaşılmıştır. Sonuç olarak, Kişilerarası İletişim Yetkinliği Envanteri'nin ayırt edici gücünün kabul edilebilir nitelikte olduğuna karar verilmiştir.

Tablo 8.

Pozitifliğin Yordanmasına İlişkin Hiyerarşik Regresyon Analizi Sonuçları

\begin{tabular}{lrrrrr}
\hline & B & Std. Hata & B & t & p \\
\hline Model 1 & & & & & \\
Sabit & 14.18 & 3.81 & & 3.72 & $<.001$ \\
Cinsiyet & .66 & .56 & .05 & 1.16 & .244 \\
Yaş & -.08 & .15 & -.02 & -.54 & .584 \\
PK & .19 & .03 & .30 & 4.97 & $<.001$ \\
GÖY & .20 & .06 & .20 & 3.30 & $<.001$ \\
\hline
\end{tabular}

Model 2 


\begin{tabular}{lrrrrr} 
Sabit & 8.23 & 3.89 & & 2.11 & .035 \\
Cinsiyet & .37 & .55 & .03 & .67 & .503 \\
Yaş & -.19 & .15 & -.05 & -1.27 & .203 \\
PK & .17 & .03 & .26 & 4.40 & $<.001$ \\
GÖY & .12 & .06 & .12 & 2.01 & .045 \\
KİY & .206 & .042 & .25 & 4.903 & $<.000$ \\
\hline Not. PK = Proaktif kişilik, GÖY = Genel öz-yeterlik, KİY = Kişilerarası iletişim yeterliği &
\end{tabular}

\section{Sonuç, Tartışma ve Öneriler}

$\mathrm{Bu}$ çalışma, kişilerarası iletişim yetkinliği kavramının sahip olduğu kuramsal yapı bağlamında değerlendirmesine olanak sağlayan Kişilerarası İletişim Yetkinliği Envanteri'nin (KIYYE) (Huang ve Lin, 2018) Türk kültürüne uyarlanmasını içermektedir. KIYE'nin Türk kültürüne uyarlanması ve psikometrik bulgularının saptanabilmesi amacıyla araştırmacılar tarafından yapılandırılmış bir süreç benimsenmiştir. $\mathrm{Bu}$ bağlamda, çalışma dört aşamada tamamlanmıştır: (i) dil geçerliği $(\mathrm{N}=45)$, (ii) yap1 geçerliği $(\mathrm{N}=208)$, (iii) güvenirlik ve madde analizi $(\mathrm{N}=211)$ ve (iv) ölçüt ve ayırt edici geçerlik $(\mathrm{N}=370)$.

Birinci aşamada $(\mathrm{N}=45)$ KIYE'nin dil geçerliği araştırılmıştır. Bu amaç doğrultusunda ilk olarak geri çeviri yöntemi (back translation method) uygulanmıştır. Daha sonra kaynak (İngilizce)hedef (Türkçe) dildeki formlar her iki dile halim katılımcılar tarafından değerlendirilmiştir. $\mathrm{Bu}$ doğrultuda her bir katılımcı ile eşleştirilmiş bir çift ölçüm elde edilmiştir. Bu ölçümlerin istatistiksel açıdan uygunluğunu değerlendirmek amacıyla bağımlı gruplar $\mathrm{t}$ testi uygulanmıştır. Bağımlı gruplar $\mathrm{t}$ testi sonuçlarına göre kaynak ve hedef dil ölçümleri arasında istatistiksel açıdan anlamlı bir farklılık bulunmamaktadır. Sonuç olarak, dil geçerliği kapsamında gerçekleştirilen prosedürel ve istatistiksel işlemlere ilişkin bulgular, kaynak (İngilizce)-hedef (Türkçe) dil versiyonlarının uyumlu olduğunu göstermektedir.

İkinci aşamada $(\mathrm{N}=208)$, KIYYE’nin yapı geçerliği incelenmiştir. KIYYE'nin yapı geçerliğini saptamak amacıyla madde analizi ve doğrulayıcı faktör analizi uygulanmıştır. Madde analizi sonucunda ölçme aracında yer alan tüm maddelerin madde-toplam korelasyonları ölçüt olarak kabul edilen .30 değerinden yüksek olduğu belirlenmiştir. Madde analizinden sonra, Huang ve Lin (2018) tarafından dört faktörlü bir yapıya sahip olduğu belirlenen KIYYE'nin Türk örnekleminde faktör yapısının uygunluğunu test etmek amacıyla doğrulayıcı faktör analizi uygulanmıştır. Doğrulayıcı faktör analizi sonuçlarına göre, dört faktörlü yapı Türk örnekleminden elde edilen verilerle iyi düzeyde uyum göstermektedir. Daha yalın bir ifade ile ölçme aracının orijinal faktör yapısının Türk örnekleminde de geçerli olduğunu destekleyen bulgular elde edilmiştir.

Üçüncü aşamada $(\mathrm{N}=211)$, KIYYE’ye ilişkin güvenirlik ve madde analizi gerçekleştirilmiştir. Güvenirlik analizi kapsamında, Cronbach Alpha ve McDonald Omega iç tutarlık katsayıları incelenmiştir. Güvenirlik analizi sonucunda elde edilen bulgular iç tutarlık katsayılarının değerlendirilmesinde ölçüt olarak kabul edilen .70 değerinin üzerindedir (Creswell, 2012). Madde analizi kapsamında, \%27'lik alt-üst grup farkları ve madde toplam korelasyonları incelenmiştir. Gerçekleştirilen analizler sonucunda, \%27'lik alt-üst grup farkları arasında istatistiksel açıdan anlamlı farkl1lıklar olduğu ve madde-toplam korelasyon değerlerinin kabul edilebilir aralıklarda olduğu belirlenmiştir. Elde edilen bulgular, KIYYE'yi oluşturan maddelerin ölçme aracının tamamı ile tutarlık gösterdiğini desteklemektedir.

Araştırmada son olarak dördüncü aşamada KIYE'nin ölçüt ve ayırt edici geçerliği incelenmiştir $(\mathrm{N}=370)$. Bu amaç doğrultusunda Kişilerarası İletişim Yetkinliği Envanteri ile İletişim Becerileri Ölçeği toplam puanları arasındaki ilişki araştırılmıştır. İki ölçme aracına ilişkin toplam puanlar arasındaki istatistiksel açıdan anlamlı ilişkinin varlığı, KIYYE'nin ölçüt geçerliğini karşıladığına ilişkin bulgular sunmaktadır. KIYYE’nin ayırt ediciliğini belirlemek amacıyla hiyerarşik 
regresyon analizi prosedürleri etkinleştirilmiştir. $\mathrm{Bu}$ bağlamda pozitiflik bağımlı değişken olarak belirlenmiştir. Kişilerarası iletişim yetkinliği, proaktif kişilik ve genel öz-yeterlik pozitifliğin olası yordayıcıları olarak analize dahil edilmiştir. Kişilerarası iletişim yetkinliğinin hiyerarşik regresyon modeline özgün katkısının istatistiksel açıdan anlamlı olması KIYYE’nin ayırt edici geçerliği sağladığının bir göstergesi olarak yorumlanabilir.

Dört farklı araştırmayı içeren bu çalışmadan elde edilen bulgular Kişilerarası İletişim Yetkinliği Envanteri’nin (KIYE) geçerli ve güvenilir bir ölçme aracı olduğunu göstermektedir. Buna göre, KIYE dört faktörden oluşan 15 maddeli beş dereceli likert tipi değerlendirmeye sahip bir ölçme aracıdır (Ek 1). Ölçme aracından elde edilebilecek puanlar 15 ile 75 arasında değişmektedir. Ölçme aracının alınan puanın yüksek olması yüksek düzeyde kişilerarası iletişim yetkinliğini göstermektedir. İfade edilen özellikleri nedeniyle, psikolojik danışmanlar, psikologlar, araştırmacılar ve öğretmenler tarafından üniversite öğrencilerinin kişişlerarası iletişim yetkinliklerinin değerlendirilmesinde KİYE'nin işlevsel olabileceği düşünülmektedir. Üniversite öğrencilerine yönelik olarak yürütülebilecek birçok çalışmada KIYE kullanılabilir. Kişilerarası iletişim yetkinliği kavramının anlamlandırılmasında, temel bileşenlerinin, belirleyicilerinin ve çıktılarının ortaya çıkarılmasında KIYE başvurulabilecek geçerli ve güvenilir bir ölçme aracıdır. Sonuç olarak, güçlü kuramsal dayanağı olan KIYY'nin, üniversite öğrencilerinin kişilerarası iletişim yetkinliklerinin başat olduğu yeni araştırmalarda kullanışlı olabileceği düşünülmektedir.

$\mathrm{Bu}$ çalışmanın bazı sınırlıkları bulunmaktadır. Bu çalışma kapsamında dört farklı araştırma yürütülmüştür ve bu araştırmalar için örneklem belirlenirken kolay ulaşılabilir örnekleme yöntemi benimsenmiştir. Dolayısıyla, bu çalışma kapsamında sunulan bulguların evrene genellenmesi zorlaşmaktadır. Farklı çalışma grupları üzerinde araştırmaların gerçekleştirilmesi elde edilen sonuçların evrene genellenebilmesini kolaylaştırabilir. Araştırma kapsamında standart prosedürler takip edilmesine rağmen, ölçme aracının zamana karşı kararlığı test edilmemiştir. Yanıtlama yanlılığı ele alınması gereken bir diğer sınırlılıktır. Araştırmaya gönüllü katılım sağlanmış olmasına rağmen, katılımcılar ölçme aracındaki ifadelere içtenlikle yanıt verilmemiş olabilir. Değerlendirilen son sınırlık sosyal istenirliktir. Katılımcılar kendilerini gerçekte olduğundan farklı bir profilde yansıtmış olabilir. Gelecek çalışmaların ifade edilen sınırlıkları giderecek ve KIYE'nin dış geçerliğini artıracak nitelikte olması önerilmektedir.

\section{Araştırmacıların Katkı Oranı}

Bu makaleye birinci yazarın \%60, ikinci yazarın $\% 40$ oranında katkısı vardır.

\section{Çıkar Çatışması}

Çalışmada çıkar çatışması oluşturabilecek herhangi bir durum yoktur.

\section{Kaynaklar}

Akın, A. ve Özcan, N. A. (2015). Short Turkish version of Proactive Scale: A study of validity and reliability. Mevlana International Journal of Education, 5(1), 165-172.

Almeida, E. P. (2004) A discourse analysis of student perceptions of their communication competence. Communication Education, 53(4), 357-364.

American Educational Research Association. (2011). Code of ethics. Retrieved March 23, 2021, from: https://www.aera.net/About-AERA/AERA-Rules-Policies/Professional-Ethics.

American Psychological Association. (2020). Publication manual of the American Psychological Association (7th ed.). Washington: American Psychological Association. 
Aydın, D. (1997). Bilişsel davranışcı yaklaşımlı grupla psikolojik danışmanın üniversite ögrencilerinin iletişim çatışmalarını önlemede etkisi, Yayımlanmamış Yüksek Lisans Tezi, Gazi Üniversitesi, Ankara.

Aydın, D. (2018). Relationship between the spiritual intelligence and self-regulation skills of education faculty students. Journal of Education and Training Studies, 6(12), 227-234.

Aypay, A. (2010). Genel Öz Yeterlik Ölçeği'nin GÖYÖ Türkçe’ye uyarlama çalışması. İnönü Üniversitesi Eğitim Fakültesi Dergisi, 11(2), 113-131.

Bateman, T. S., and Crant, J. M. (1993). The proactive component of organizational behavior: A measure and correlates. Journal of Organizational Behavior, 14(2), 103-118.

Beebe, S., Beebe, S. J., and Redmond, M. (2014). Interpersonal communication: Relating to others (7th ed.). Essex: Pearson.

Bochner, A. P., and Kelly, C. W. (1974). Interpersonal competence rationale, philosophy and implementation of a conceptual framework. Speech Teacher, 23, 279-301.

Bodie, G. D. (2011). The understudied nature of listening in interpersonal communication: Introduction to a special issue. The International Journal of Listening, 25(1-2), 1-9.

Brislin, R. W. (1970). Back-translation for cross-cultural research. Journal of Cross-Cultural Psychology, 1, 185-216.

Bubas, G. (2001). Toward competence in interpersonal communication: Constitutive traits, skills, and dimensions. World Futures, 57, 557-581.

Buluş, M., Atan, A. ve Erten Sarıkaya, H. (2017). Etkili iletişim becerileri: bir kavramsal çerçeve önerisi ve ölçek geliştirme çalışması. International Online Journal of Educational Sciences, 9(2), 575-590.

Caprara, G. V., Alessandri, G., Eisenberg, N., Kupfer, A., Steca, P., Caprara, M. G., and Abela, J. (2012). The Positivity Scale. Psychological Assessment, 24, 701-712.

Carl, W. J., and Duck, S. (2004). How to do things with relationships ... and how relationships do things with us. Annals of the International Communication Association, 28(1), 1-35.

Carrell, L. J., and Willmington, S. C. (1996). A comparison of self-report and performance data in assessing speaking and listening competence. Communication Reports, 9(2), 185-191.

Creswell, J. W. (2012). Educational Research: Planning, Conducting, and Evaluating Quantitative and Qualitative Research (4th ed.). New York: Pearson.

Çıkrıkçı, Ö., Çiftçi, M. ve Gençdoğan, B. (2015). Pozitiflik Ölçeği Türkçe formu'nun psikometrik özellikleri. The Journal of Happiness \&Well-Being, 3(1), 57-76.

Dağıstan, A. ve Çalıșkan, N. (2018). İletișim becerileri üzerine bir araștırma "öğretmen adaylarının kalıplaşmış düşünce eğilimleri”. Ahi Evran Üniversitesi Sosyal Bilimler Enstitüsü Dergisi, 4(2), 123-133.

Ersanlı, K. ve Balcı, S. (1998). İletişim Becerileri Envanterinin geliştirilmesi: Geçerlik ve güvenirlik çalışması. Türk Psikolojik Danışma ve Rehberlik Dergisi, 2(10), 7-12. 
Graham, E. E., and Shue, C. K. (2001). Reflections on the past, directions for the future: A template for the study and instruction of interpersonal communication. Communication Research Reports, 18(4), 337-348.

Graham, E. E., Papa, M. J., and Brooks, G. P. (1992). Functions of humor in conversation: Conceptualization and measurement. Western Journal of Communication, 56(2), 161-183.

Hambleton, R. K. (2005). Issues, designs and technical guidelines for adapting tests into multiple languages and cultures. In R.K. Hambleton, P.F. Merenda \& S.D. Spielberger (Eds.), Adapting educational and psychological tests for cross-cultural assessment (pp. 3-38). New Jersey: Lawrence Erlbaum Associates.

Huang, Y. C., and Lin, S. H. (2018). An inventory for assessing interpersonal communication competence of college students. British Journal of Guidance \& Counselling, 46(4), 385-401.

Mehmet, K. ve Çalışkan, N. (2019). Ahilik ve iletişim: Nitel bir çalışma. Ahi Evran Üniversitesi Sosyal Bilimler Enstitüsü Dergisi, 5(1), 93-111.

Klemmer, E. T., and Snyder, F. W. (1972). Measurement of time spent communicating. Journal of Communication, 22(2), 142-158.

Kline, R. B. (2016). Principles and practice of structural equation modeling (4th ed.). Guilford Press.

Koca, G. Ş. ve Erigüç, G. (2017). İletişim Yeterlilik Ölçeği'nin geçerlik ve güvenilirliği. Uluslararası Yönetim İktisat ve Issletme Dergisi, 13(4), 789-799.

Korkut, F. (1996). İletişim Becerileri Değerlendirme Ölçeğinin geliştirilmesi: Güvenirlik ve geçerlik çalışmaları. Türk Psikolojik Danışma ve Rehberlik Dergisi, 2(7), 18-23.

Korkut-Owen, F. ve Bugay, A. (2014). İletişim Becerileri Ölçeği'nin geliştirilmesi: geçerlik ve güvenirlik çalışması. Mersin Üniversitesi Eğitim Fakültesi Dergisi, 10(2), 51-64.

McCroskey, J. C. (1982). Oral communication apprehension: A reconceptualization. Annals of the International Communication Association, 6(1), 136-170.

Miller, J. B., and de Winstanley, P. A. (2002). The role of interpersonal competence in memory for conversation. Personality and Social Psychology Bulletin, 28(1), 78-89.

Rogers, C. R. (1975). Empathic: An unappreciated way of being. The Counseling Psychologist, 5(2), $2-10$.

Rubin, R. B., and Martin, M. M. (1994). Development of a measure of interpersonal communication competence. Communication Research Reports, 11(1), 33-44.

Schwarzer, R., and Jerusalem, M. (1995). Generalized Self-Efficacy Scale. J. Weinman, S. Wright, \& M. Johnston (Ed.), Measures in Health Psychology: A User's Portfolio. Causal and Control Beliefs (pp. 35-37). Windsor: NFER-Nelson.

Spitzberg, B. H. (1983). Communication competence as knowledge, skill, and impression. Communication Education, 32(3), 323-329.

Spitzberg, B. H., and Cupach, W. R. (1984) Interpersonal communication competence. Beverly Hills: Sage. 
Webb, L., and Thompson-Hayes, M. (2002). Do popular collegiate textbooks in interpersonal communication reflect a common theory base? A telling content analysis. Communication Education, 51(2), 210-224.

Wilson, S. R., and Sabee, C. M. (2003). Explicating communicative competence as a theoretical term. In J. O. Greene and B. R. Burleson (Eds.), Handbook of Communication and Social Interaction Skills (pp. 3-50). NJ: Erlbaum. 


\section{Extended Abstract}

\section{Introduction}

Communication is at the center of human existence. The vast majority of people spend between $80 \%$ and $90 \%$ of their time communicating with other people (Klemmer \& Snyder, 1972). Through this interaction, the development of interpersonal relationships has been provided (Graham \& Shue, 2000). In order to understand interpersonal communication, communication should be considered in two basic categories: communication as a general concept (i) and human communication (ii). In a general context, communication is the process of activating information (Beebe, Beebe, \& Redmond, 2014). Human communication can be assessed as the process of making sense of the world. Furthermore, human communication is the sharing of the meaning created by verbal and non-verbal messages with other people in the signification process mentioned above (Carl \& Duck, 2004). Interpersonal communication has an important distinguishing feature, such as the ability to manage relationships. Interpersonal communication cannot be defined only by the number of people with whom it is communicated. In interpersonal communication, the quality of communication has a very important function. Interpersonal communication becomes apparent when the existence of other individuals is respected. Being competent in the communication process is a desired achievement (Beebe et al., 2014). Being competent in the communication process requires reacting effectively and appropriately to perceived messages (Wilson \& Sabee, 2003). Understanding the messages conveyed by other people and creating the desired effect of the message is an indication that the individual is able to communicate effectively (Beebe et al., 2014). These inferences highlight the concept of interpersonal communication competence. In general, the ability of a person to listen to the speaker effectively, to relax in the social environment, to empathize with other people, and to interact with other people in a meaningful way can be interpreted as indicators of competence in interpersonal communication. In the current paper, it was aimed to adapt the Interpersonal Communication Competence Inventory (ICCI) into Turkish.

\section{Method}

In the present study, it was aimed to conduct a Turkish adaptation study of the Interpersonal Communication Competence Inventory (ICCI) developed by Huang and Lin (2018). In this context, four studies were conducted independently. Language equivalence $(\mathrm{N}=45)$, structural validity $(\mathrm{N}=$ $208)$, reliability and item analysis $(\mathrm{N}=211)$, convergent and discriminant validity $(\mathrm{N}=370)$ were examined in order to determine the validity and reliability of ICCI. A two-step process was followed for language equivalence. First, the back translation method was applied. After the back translation process, participants who had good command of the source and target language were asked to evaluate the English and Turkish forms. The structural validity of ICCI was tested by confirmatory factor analysis. Cronbach Alpha and McDonald Omega coefficients were examined within the scope of reliability analysis. To determine the convergent validity, correlation values between the total scores of ICCI and the Communication Skills Scale were calculated. Finally, hierarchical regression analysis was applied to determine the discriminant validity of ICCI. The ethical consideration of the study was approved by the Social and Humanities Ethics Committee of the state university where the second author has worked (29.09.2020; Decision No: 2020-75).

\section{Findings}

In order to statistically determine the language equivalence of the ICCI, the forms of the target and source language were compared. According to the dependent group t-test results, there was no statistically significant difference between the Turkish and English forms of ICCI ( $\mathrm{t}(44)=.126$, p > $.05)$. In line with the findings, it can be stated that ICCI provides language equivalence. According to the confirmatory factor analysis results, the four-factor model had a good fit to the data $(\mathrm{x} 2 / \mathrm{df}=1.59$, RMSEA $=.054 \%$ 90CI $[.036, .070], \mathrm{TLI}=.91, \mathrm{CFI}=.93, \mathrm{GFI}=.92, \mathrm{SRMR} .=.05$; $\mathrm{AIC}=206.65$, $\mathrm{ECVI}=1.0090 \% \mathrm{CI}[.868,1.170])$. Reliability analysis revealed that ICCI was a reliable measure $(\alpha$ 
$=.78 ; \omega=.80)$. The internal consistency coefficients of the sub-dimensions of ICCI were above the accepted criterion .70 (Listening Skill $[\alpha=.73 ; \omega=.73]$; Social Relaxation Skill $[\alpha=.71 ; \omega=.73]$; Empathy Skill $[\alpha=.76 ; \omega=.78]$, Expressiveness Skill $[\alpha=.78 ; \omega=.80])$. Therefore, it would be stated that the sub-factors also have a reliable structure. The relationships between the total scores of the Interpersonal Communication Competence Inventory and the Communication Skills Scale were examined within the scope of convergent validity. Correlation analysis showed that there was a significant positive relationship between the total scores of the Interpersonal Communication Competence Inventory and the Communication Skills Scale $(r=.78, p<.01 ; 95 \% \mathrm{CI}=.73, .82)$. Within the scope of the discriminant validity of the Interpersonal Communication Competence Inventory, positivity was determined as the dependent variable; age, gender, proactive personality, self-efficacy, and interpersonal communication competence were assessed as independent variables. When the hierarchical regression model summary was evaluated, it was concluded that interpersonal communication competence had a significant contribution to accounting positivity $\left(\mathrm{R}^{2}\right.$ change $\left.=5 \%\right)$. As a result, it would be concluded that the Interpersonal Communication Competence Inventory met the discriminant validity

\section{Conclusion, Discussion and Recommendations}

The results showed that the Interpersonal Communication Competence Inventory (ICCI) was a valid and reliable measure. Accordingly, ICCI is a 15-item five-point Likert-type assessment measure consisting of four factors. The scores that can be obtained from the measure range between 15 and 75 . The high score of the measure indicates a high level of interpersonal communication competence. Due to its stated features, it was thought that ICCI could be functional in evaluating the interpersonal communication competencies of university students by psychological counselors, psychologists, researchers, and teachers. ICCI would be used in many studies that can be carried out for university students. It is a valid and reliable measure that can be used to make sense of the concept of interpersonal communication competence and to reveal its basic components, determinants, and outputs. As a result, it was thought that ICCI, which has a strong theoretical basis, can be useful in future studies where interpersonal communication competencies of university students will be dominant. 


\section{EKLER}

Ek 1. Kişilerarası İletişim Yetkinliği Envanteri (KIYYE)

\section{Kişilerarası İletişim Yetkinliği Envanteri (KiYE)}

1 DB1 Arkadaşlarımla yaptığım sohbetlerde ne hakkında konuştuğumuzu bilirim.

2 DB2 Konuşma sırasında başkalarını dikkatlice dinlerim.

3 DB3 Diğerleri benimle konuşurken onlara olumlu geribildirim veririm.

4 DB4 Çoğu durumda sohbetlere ilgi gösteririm.

5 SRB1 Yeni insanlarla iyi geçinmek benim için zor değildir.

6 SRB2 Başkalarına nasıl hissettiğimi doğal bir biçimde belli ederim.

7 SRB3 Yeni arkadaşlar tanımak hoşuma gider.

8 SRB4 Yabancılarla konuşurken rahat ve sakinimdir.

9 EB1 Başkalarıyla konuşurken her zaman onların nasıl hissettiklerini düşünürüm.

10 EB2 Başkalarının ne hissettiğine çok fazla dikkat etmem.

11 EB3 Tartışırken kendimi başka birinin yerine koyabilirim.

12 EB4 Karşımdaki kişinin ihtiyaç ve duygularına karşı duyarlıyım.

13 İB1 Kendimi ifade etmek için doğru kelimeyi bulmakta zorlanırım.

14 İB2 Başkalarıyla etkileşime girdiğimde kendimi açıça ifade edebilirim.

15 İB3 Başkalarına bazı şeyleri anlatırken sıklıkla farklı yüz yüz ifadeleri kullanırım.

Not. Kişilerarası İletişim Yetkinliği Envanteri (KİYE) beş dereceli likert tipi bir değerlendirmeye sahiptir $(1=$ Bana Tamamen Uygun Değil, ..., 5 = Bana Tamamen Uygun). Alt Faktörler: DB = Dinleme Becerisi (1., 2., 3. ve 4. madde), SRB = Sosyal Rahatlık Becerisi (5., 6., 7. ve 8. madde), $\mathrm{EB}=$ Empati Becerisi (9., 10., 11. ve 12. madde), İB = İfade Becerisi (13., 14. ve 15 . madde). 10 . ve 13. madde ters puanlanır. 